\title{
Evaluation of Condom Use among University Undergraduates in Port Harcourt, Nigeria
}

\author{
Emmanuel Okwudili Oranu ${ }^{1}$, Prince Atochi Woruka1, Esther Nonye-Enyindah ${ }^{2}$ \\ ${ }^{1}$ Department of Obstetrics and Gynaecology, University of Port Harcourt Teaching Hospital, Port Harcourt, Nigeria \\ ${ }^{2}$ Department of Obstetrics and Gynaecology, Rivers State University Teaching Hospital, Port Harcourt, Nigeria \\ Email: *meetemma24@gmail.com, *emmanuel.oranu@uniport.edu.ng
}

How to cite this paper: Oranu, E.O., Woruka, P.A. and Nonye-Enyindah, E. (2020) Evaluation of Condom Use among University Undergraduates in Port Harcourt, Nigeria. Journal of Biosciences and Medicines, 8, 31-41.

https://doi.org/10.4236/jbm.2020.85004

Received: March 1, 2020

Accepted: April 27, 2020

Published: April 30, 2020

Copyright $\odot 2020$ by author(s) and Scientific Research Publishing Inc. This work is licensed under the Creative Commons Attribution International License (CC BY 4.0).

http://creativecommons.org/licenses/by/4.0/

\begin{abstract}
Background: Barrier contraception has the beauty of dual protection-against pregnancy and sexually transmitted infections. Following the persisting burden of unsafe abortion and human immunodeficiency virus (HIV), much sensitization/campaign has been ongoing in the past few decades by government and non-governmental organisations (NGOs) in Nigeria against unprotected sexual intercourse. The youth are generally assumed to have high risk sexual behaviour, hence this study on Port Harcourt university undergraduates. Objectives: To determine the awareness and use of condom among University undergraduates in Port Harcourt. Methods: The study was a prospective descriptive cross-sectional study of 636 undergraduate students of the University of Port Harcourt and Rivers state University, South-south Nigeria. The multistage sampling technique was used to randomly select participants and data collected using a pretested structured self administered questionnaire. Data was analyzed using version 23.0 SPSS and reported in means, frequencies and percentages. Probability value was set at $5 \%(\mathrm{p}<0.05)$ at a confidence interval of 95\%. Result: Majority of the undergraduates (58.4\%) had their first sexual intercourse at $\leq 19$ years. A total of $580(97.8 \%)$ and $467(78.9 \%)$ were aware of male and female condoms respectively. However, a statistically significant number of sexually active undergraduates had unprotected sexual intercourse $\left(p<0.001 ; \chi^{2}=200.602\right)$. Only $5.5 \%$ of the respondents in this study were willing to know their HIV status. Conclusion: There is a high level of condom awareness among Port Harcourt University undergraduates. Surprisingly, their practice of unprotected sexual intercourse is still high.
\end{abstract}

\section{Keywords}

Condom Use, Unprotected Intercourse, Port Harcourt 


\section{Introduction}

Nigeria has the second highest burden of Human Immunodeficiency Virus (HIV) worldwide with about 3.6 million people living with the virus [1]. Young people contribute $35 \%$ of new infections each year [2] [3]. This higher prevalence of HIV infection among Nigerian undergraduates has been attributed to their high level unprotected sexual intercourse with multiple sexual partners [4] [5] [6]. This sexual behaviour is also responsible for the rising incidence of sexually transmitted diseases, unwanted pregnancy, induced miscarriages, and post abortal complications seen among Nigerian undergraduates [7] [8].

Majority of Nigerian undergraduates have the knowledge that the use of condom during sexual intercourse can be effective in preventing sexually transmitted disease and unwanted pregnancy [7]. However, a significant percentage does not consistently use condom during sexual intercourse [9]. Barriers to male condom use identified among Nigerian undergraduates are reduced pleasure during sex, partners' decision, not protective for pregnancy, difficult to use, not affordable, allergy to latex, not readily available, and religion [10] [11]. There is also a very poor knowledge and use of female condom among the Nigerian Undergraduates [12], which primarily has been attributed to unavailability and difficulty in using it [13] [14] [15].

Studies have shown that $68 \%$ of undergraduates in South-eastern Nigeria are sexually active, $17.9 \%$ of these undergraduates have more than two sexual partners per year and $13.7 \%$ have more than five sexual partners per year [15]. Similar reports of high level of unprotected sexual intercourse with multiple sexual partners among University undergraduates have been reported in Southern Nigeria [11], North central Nigerian [10], Ethiopia [16] and China [17]. The factors responsible for this multiple sexual partners are satisfying sexual urge, peer pressure, ignorance, promiscuity, and sexual addiction [18]. About $73.7 \%$ of undergraduates in south eastern Nigeria have sex for pleasure [5] and 15.2\% of undergraduates have been reported to have sexual addiction [19].

Majority of Nigerian undergraduates have the knowledge that the use of condom during sexual intercourse can be effective in preventing sexually transmitted disease and unwanted pregnancy [7]. However, a significant percentage does not consistently use condom during sexual intercourse [9]. In south eastern Nigeria, $96.4 \%$ of undergraduate know how to use the male condom and only $68.8 \%$ undergraduates have ever used it before [20]. Another study reported that only $47.3 \%$ of undergraduates in southern Nigeria use male condom consistently [21]. A study among students in south-south Nigeria reported a low practice of condom use and is barely boarded about sexually transmitted diseases and unwanted pregnancies [9]. Studies have also reported that only $33.2 \%$ of students in Ethiopia [22] and 30\% of students in China [17] use condom consistently. In Akwa Ibom state south-south Nigeria, barriers to condom use identified among undergraduates were stigma attached to condom use because of its association with HIV, familiarity with sex partners and perception that condom use reduces 
sexual satisfaction and hinders sexual interest [11] Another study among undergraduates in south eastern Nigeria showed that religious belief (33.3\%) was the commonest reason why most undergraduates don't use condom [20].

A study among undergraduates in south eastern Nigeria reported that $62 \%$ of the students were aware of female condom however only $5.1 \%$ of students have ever used a female condom [20]. Another study among undergraduates however reported that $64.3 \%$ of undergraduates had knowledge of female condom, however only $32.9 \%$ of respondents agreed that female condom can protect against STDs, HIV [23]. In a study to investigate the perceived confidence to use the female condoms amongst undergraduate female students from selected tertiary institutions in south western Nigeria, only $10.8 \%$ of respondent had confidence to use a female condom [13]. However, in southern Nigeria, a study among undergraduates reported that $89.3 \%$ were aware of female condom, only $8.9 \%$ had ever used one due to unavailability, high cost, and difficulty with its insertion [14]. In a Camerounian study, $67.3 \%$ of respondents were aware of female condom, however only $8.0 \%$ have ever used it before [12]. In view of the high rates of risky sexual practices and higher HIV prevalence rate among undergraduates, and the effectiveness of condom in the prevention of sexually transmitted diseases and unwanted pregnancies, it has become important to review the current knowledge and actual practice of condom usage among University undergraduates in Port Harcourt, south-south Nigeria.

\section{Methodology}

Study location: The study was carried out at the University of Port Harcourt and Rivers State University, Port Harcourt.

Study population: Male and female undergraduate students of the University of Port Harcourt and Rivers state University who are between the ages of 18 and 40 years.

\section{Inclusion criteria:}

- Students who have a form of identification;

- Students who are within the stated age limit and gave consent;

\section{Exclusion criteria:}

- Students that were not in class during the study.

Study design: The study was a prospective descriptive cross-sectional study of 636 undergraduate students of Port Harcourt University.

Sample size estimation: Sample size was estimated using the formula:

$$
n=Z^{2} p(I-p) / d^{2}
$$

where:

- $Z$ is the test statistic at $95 \%$ confidence interval given as 1.96 ;

- $p=$ Prevalence of condom use among undergraduates in southern Nigeria, given as $47.3 \%$ [21];

- $d=$ Tolerable error set at 0.05 . 
Using the above formula, a minimum sample size of 385 was estimated. Ten percent attrition was considered to accommodate for non-response, giving a value of 424 . The sample size was further multiplied by 1.5 to cater for design effect since multistage sampling technique was used which brought the sample size to 636 .

Sampling method: A multistage sampling method was used. The sampling method consisted of four stages.

Stage One (Selection of Faculties): Six faculties were randomly selected from the twelve faculties of the University.

Stage Two (Department selection): Two departments were selected from each of the selected faculty.

Stage Three (year of study selection): Students at two different years of study were selected from each of the selected department.

Stage Four (Students Selection): A minimum of 12 students were randomly selected from each year of study to achieve the sample size. This is for each of the Universities.

Study procedure: The instrument for data collection was a structured selfadministered questionnaire developed from modification of previous questionnaires used in similar studies. Verbal consent was obtained after explanation of the study in the class and only students who gave consent received the questionnaires.

Data analysis: Data was entered into the Micro Soft Excel (2016) spread sheet, and later exported to version 23.0 of the Statistical Package for Social Science (SPSS) statistical software for analysis. Descriptive statistics were conducted and reported as means and standard deviation for continuous variables, and as frequencies and percentages for categorical variables. Inferential statistics was done using the Chi-Square test, to test for statistically significant variables. The level of significance was set at a probability level of $5 \%(\mathrm{p}<0.05)$ at $95 \%$ confidence interval.

Ethical considerations: Ethical clearance for the study was obtained from the University of Port Harcourt Ethical Committee.

\section{Results}

A total of 636 questionnaires were distributed to undergraduate students of the two universities. Five hundred and ninety-three (593) of the questionnaires were retrieved and analysed, giving a response rate of $93.2 \%$.

Two hundred and sixty three (44.4\%) respondents were males and 330 (55.6\%) were females. Most (41.8\%) were between 20 and 25 years. A greater number of them (91.2\%) were single (Table 1$)$.

Five hundred and thirty nine (90.9\%) of the respondents have had sexual intercourse and $38.6 \%$ had multiple sexual partners in the past 12 months (Table 2). The reasons for sexual intercourse were pleasure (68.8\%), money (15.2\%), forced (6.5\%), and 51 (9.5\%) gave no response to this question.

In Table 3, 580 (97.8\%) of the respondents had knowledge of male condom and most of them heard it from their friends (74.0\%). More than one third (77.6\%) 
of the respondents have used condom (male condom) during sexual intercourse but only 347 (58.5\%) used it consistently.

Table 4 showed that $60.9 \%$ of the respondents feel that the use of condom can prevent pregnancy and sexually transmitted diseases. While in Table 5, the major complaints of those who did not use condom regularly were reduced pleasure (57.1\%), not reliable to prevent pregnancy (44.2\%) or partner dislike (43.2\%).

Four hundred and sixty-seven $(78.8 \%)$ of the respondents had heard about the female condom, but only 116 (19.6\%) had used it (Table 6).

Two hundred and thirty eight respondents (40.1\%) do not know their HIV status and only 13 respondents (5.5\%) were willing to get tested for HIV (Table 7).

Table 1. Socio-demographic data.

\begin{tabular}{ccc}
\hline & Frequency $(\mathrm{n}=593)$ & Percentage \\
\hline Gender & 263 & \\
Male & 330 & 44.4 \\
Female & & 55.6 \\
Age & 127 & \\
$\leq 19$ years & 248 & 21.4 \\
$20-25$ years & 218 & 41.8 \\
$>25$ years & & 36.8 \\
Marital status & 541 & \\
Single & 52 & 91.2 \\
Married & & 8.8 \\
\hline
\end{tabular}

Table 2. Sexual history.

Frequency $(n=593) \quad$ Percentage

Ever had sexual intercourse

$\begin{array}{lcc}\text { Yes } & 539 & 90.9 \\ \text { No } & 54 & 9.1\end{array}$

Age at first sexual intercourse $593-54(n=539)$

$\begin{array}{lcc}\leq 19 \text { years } & 315 & 58.4 \\ 20-25 \text { years } & 199 & 37.0 \\ >25 \text { years } & 25 & 4.6\end{array}$

Number of sexual partners in the past

12 months $593-54(n=539)$

$\begin{array}{lcc}\text { None } & 134 & 24.9 \\ \text { One } & 197 & 36.5 \\ & 208 & 38.6\end{array}$


Table 3. Knowledge and use of male condom.

\begin{tabular}{|c|c|c|}
\hline & Frequency $(n=593)$ & Percentage \\
\hline \multicolumn{3}{|c|}{ Knowledge of condom } \\
\hline Yes & 580 & 97.8 \\
\hline No & 13 & 2.2 \\
\hline \multicolumn{3}{|c|}{ Source of information $(n=580)$} \\
\hline Friends & 429 & 74.0 \\
\hline Social media & 113 & 19.5 \\
\hline Clinical personnel & 31 & 5.3 \\
\hline Others & 7 & 1.2 \\
\hline \multicolumn{3}{|c|}{ Ever used condom during sexual intercourse } \\
\hline Yes & 460 & 77.6 \\
\hline No & 133 & 22.4 \\
\hline \multicolumn{3}{|c|}{$\begin{array}{l}\text { Consistent use of condom during } \\
\text { sexual intercourse }(n=593)\end{array}$} \\
\hline Yes & 347 & 58.5 \\
\hline No & 246 & 41.5 \\
\hline
\end{tabular}

Table 4. Factors influencing use of male condom.

\begin{tabular}{ccc}
\hline & Frequency $(\mathrm{n}=593)$ & Percentage \\
\hline Reasons for regular use of condom & & \\
For prevention of pregnancy and infection & 361 & 60.9 \\
For protection of infection & 126 & 21.2 \\
For prevention of pregnancy & 106 & 17.9 \\
\hline
\end{tabular}

Table 5. Limitations to use of male condom.

\begin{tabular}{ccc}
\hline & Frequency (multifactorial) & Percentage \\
\hline Reasons for not using condom regularly & 168 & \\
Reduces pleasure & 130 & 57.1 \\
Not reliable in preventing pregnancy/infection & 127 & 44.2 \\
Partner's dislike & 82 & 43.2 \\
Difficult to use & 77 & 27.9 \\
Not affordable & 58 & 26.2 \\
Reacts to condom & 58 & 19.7 \\
Not available & 46 & 19.7 \\
Religious reason & & 15.6 \\
\hline
\end{tabular}


Table 8 shows that condom use was significantly higher among respondents older than 25 years $(91.2 \%)$, and least among those who were 19 years or less (59.2\%) $\left(\mathrm{p}<0.001 ; \chi^{2}=48.582\right)$. It was also found that condom use was significantly higher among married men (96.1\%) than among single men (77.7) $(\mathrm{p}=$ $\left.0.002 ; \chi^{2}=9.581\right)$. Among the respondents who reported that they had had sex before, about $72(13.5 \%)$ of them had sex without condom as compared to those who had sex with condom (86.5\%), and this difference was statistically significant $\left(\mathrm{p}<0.001 ; \chi^{2}=200.602\right)$.

Table 6. Knowledge and use of female condom $(\mathrm{n}=593)$.

\begin{tabular}{ccc}
\hline & Yes (\%) & No (\%) \\
\hline Ever heard of female condom & $467(78.8)$ & $126(21.2)$ \\
Ever seen female condom & $284(47.9)$ & $309(52.1)$ \\
Ever used female condom & $116(19.6)$ & $477(80.4)$
\end{tabular}

Table 7. Attitude towards HIV screening $(\mathrm{n}=593)$.

\begin{tabular}{ccc}
\hline & Yes (\%) & No (\%) \\
\hline Do you know your HIV status & $355(59.9)$ & $238(40.1)$ \\
Are you willing to know your HIV status & $13(5.5)$ & $225(94.5)$ \\
\hline
\end{tabular}

Table 8. Association of condom use with socio-demographic characteristics.

\begin{tabular}{|c|c|c|c|c|}
\hline \multirow[b]{2}{*}{ Variable } & \multicolumn{2}{|l|}{ Use Condom } & \multirow[b]{2}{*}{$x^{2}$} & \multirow[b]{2}{*}{ p-value } \\
\hline & $\begin{array}{c}\text { Yes }(\%) \\
\mathrm{n}=\mathbf{4 6 0}(\text { ever used condom })\end{array}$ & $\begin{array}{l}\text { No }(\%) \\
\mathrm{n}=120\end{array}$ & & \\
\hline \multicolumn{5}{|l|}{ Gender } \\
\hline Male & $203(78.4)$ & $56(21.6)$ & 0.248 & 0.619 \\
\hline Female & $275(80.1)$ & $64(19.9)$ & & \\
\hline \multicolumn{5}{|l|}{ Age (years) } \\
\hline$\leq 19$ & $71(59.2)$ & $49(40.8)$ & 48.582 & $<0.001^{*}$ \\
\hline $20-25$ & $191(78.6)$ & $52(21.4)$ & & \\
\hline$>25$ & $198(91.2)$ & $19(8.8)$ & & \\
\hline \multicolumn{5}{|c|}{ Marital Status } \\
\hline Single & $411(77.7)$ & $118(22.3)$ & 9.581 & $0.002^{*}$ \\
\hline Married & $49(96.1)$ & $2(3.9)$ & & \\
\hline \multicolumn{5}{|c|}{ Ever had sex } \\
\hline Yes & $460(86.5)$ & $72(13.5)$ & 200.602 & $<0.001^{*}$ \\
\hline No & $0(0.0)$ & $120(100.0)$ & & \\
\hline
\end{tabular}

${ }^{*}$ Statistically significant. 


\section{Discussion}

More than half (58.4\%) of the undergraduates in this study had their first sexual intercourse at $\leq 19$ years, which means they already have sexual exposure as teenagers probably before getting admission into the University. It had also been reported that majority of these teenager who engage in sex just for pleasure, have poor sex education [5]. This is not surprising as in most African tradition, it is considered inappropriate for a young person to discuss sex related matters before marriage, therefore teenagers have little or no sex education at home. Our educational system is also contributory, as most of our primary and secondary schools and even the Universities do not include sex education as part of its curriculum. The teenager is then left with the social media and friends for sex education leading to misinformation and early sexual adventures [20]. Early sexual exposure is usually associated with unprotected sexual intercourse with multiple sexual partners [11]. This was reflected in this study were $38.6 \%$ of undergraduates had multiple sexual partners and almost half (40.8\%) of teenage undergraduates had unprotected sexual intercourse. This is higher than findings in South-eastern Nigeria, were $17.9 \%$ of undergraduates have more than two sexual partners per year and $13.7 \%$ have more than five sexual partners per year [5]. It then means that this deplorable situation is getting worse.

The awareness on condom use among undergraduates was 580 (97.8\%) for male condom and 467 (78.9\%) for female condom. This is higher than findings at the Nnamdi Azikiwe University, where $96.4 \%$ of undergraduates were aware of male condom and $62.3 \%$ were aware of female condom [20]. However, this high level of awareness does not reflect in their attitude towards use of condom (female condom use was as low as $19.6 \%$ in this study). A statistically significant number of sexually active undergraduates in this study had unprotected sexual intercourse $\left(p<0.001 ; \chi^{2}=200.602\right)$. Among the undergraduates that have ever used condom, only $286(62.2 \%)$ used it consistently. This is higher than a previous report in South-west and South-south Nigeria where only $47.3 \%$ of undergraduates used condom consistently [21]. The low use of condom is probably due to the source of the information. In this study, majority of the undergraduates got the awareness of condom use from either friends (74.0\%) or the social media (19.5\%). A study in South-east Nigeria also noted that friends and social media were the commonest sources on information on condom use [20]. These sources may give incomplete or totally false information. Other major limitations to condom use among these undergraduates in this study were reduced pleasure (57.1), not reliable to prevent pregnancy or infection (44.2), and partner's dislike (43.2). These similar limitations were reported by Brian et al. [5].

Unprotected sexual intercourse with multiple sexual partners explains the higher prevalence of $3.69 \%$ [4] of HIV among undergraduates compared to the national average of $3.6 \%$ [1]. A more worrisome issue is that only $5.5 \%$ of respondents in this study were willing to know their HIV status despite the fact that HIV counselling and testing is free in most government hospital. This is 
scaring. A study in south-south Nigeria had also reported that most undergraduate had little or no regard for sexually transmitted diseases or unwanted pregnancies [9] [24]. If not stopped, this current trend will lead to an increase in HIV, STI, unwanted pregnancy and their associated complications, limiting the possibility of achieving the sustainable developing goals.

\section{Conclusion}

Though the awareness of condom use is high among undergraduates in this study, consistent use of condom during sexual intercourse was worrisomely poor.

\section{Recommendation}

There is a dare need to step up ongoing sensitization/counselling efforts on the benefits of the use of condom during sexual intercourse and particularly re-echoing the consequences of unprotected sexual intercourse among our youth and the society at large.

\section{Limitation}

The limitation to this study included the fact that the data is not large enough. Hence the study remain preliminary, hence further enlarged study is needed.

\section{Conflicts of Interest}

The authors declare no conflicts of interest regarding the publication of this paper.

\section{References}

[1] UNICEF. Nigeria Country Program Document 2014-2017. https://www.unicef.org/nigeria/resources_8471.html

[2] Aladeniyi, O.B., Bodunwa, O.K. and Sonde, M. (2017) Statistical Analysis of Reported Cases of Sexually Transmitted Diseases. International Journal of Statistics and Applications, 7, 186-191.

[3] Awofala, A.A. and Ogundele, O.E. (2016) HIV Epidemiology in Nigeria. Saudi Journal of Biological Sciences, 30, 30.

[4] Nwabunnia, I.E., Ibeh, B.O. and Ogbulie, T.E. (2014) High HIV Sero-Prevalence among Students of Institutions of Higher Education in Southeast Nigeria. Asian Pacific Journal of Tropical Disease, 4, 159-165. https://doi.org/10.1016/S2222-1808(14)60334-0

[5] Brian, A.J.I., Umeononihu, O., Echendu, A.D. and Eke, N. (2016) Sexual Behaviour among Students in a Tertiary Educational Institution in Southeast Nigeria. Advances in Reproductive Sciences, 4, 87-92. https://doi.org/10.4236/arsci.2016.43010

[6] Envuladu, E.A., Anke, K., Zwanikken, P. and Zoakah, A.I. (2017) Sexual and Reproductive Health Challenges of Adolescent Males and Females in Some Communities of Plateau State Nigeria. International Journal of Psychology and Behavioral Science, 7, 55-60.

[7] Mehra, D., Stergren, P., Ekman, B. and Agardh, A. (2014) Inconsistent Condom Use among Ugandan University Students from a Gender Perspective: A Cross-Sectional 
Study. Global Health Action, 7, Article ID: 22942.

https://doi.org/10.3402/gha.v7.22942

[8] Oyefabi, A.O., Nmadu, A.G. and Yusuf, M.S. (2016) Prevalence, Perceptions, Consequences, and Determinants of Induced Abortion among Students of the Kaduna State University, Northwestern Nigeria. Journal of Tropical Medicine, 18, 86-92. https://doi.org/10.4103/2276-7096.192230

[9] Izekor, S., Osifo, U.C., Orhue, P.O., Momoh, A.R.M. and Airhomwanbo, K.O. (2014) Knowledge and Practice of Condom-Usage among Undergraduate Students in Edo State, Nigeria. International Journal of Community Research, 3, 12-18.

[10] Chingle, M.P., Odunze, P.A., Mohammed, A., Bitto, T.T., Sodipo, O.Y. and Zoakah, A.I. (2017) Predictors of Male Condom Utilization in Plateau State, Nigeria. Nigerian Journal of Clinical Practice, 20, 1079-1087. https://doi.org/10.4103/njcp.njcp_56_17

[11] Asa, U.A. and Nkan, V.V. (2015) Barriers to Condom Use by Youths in Rural Areas of Akwa Ibom State, Nigeria. American Journal of Research Communication, 3, 14-22.

[12] Tarkang, E.E. and Bain, L.E. (2015) Knowledge, Attitudes and Utilisation of the Female Condom among High School Female Students in Kumba, Cameroon. British Journal of Education, Society \& Behavioural Science, 5, 169-180. https://doi.org/10.9734/BJESBS/2015/13048

[13] Obembe, T.A., Adebowale, A.S. and Odebunmi, K.O. (2017) Perceived Confidence to Use Female Condoms among Students in Tertiary Institutions of a Metropolitan City, South-Western, Nigeria. BMC Research Notes, 10, 398. https://doi.org/10.1186/s13104-017-2730-6

[14] Tobin-West, C.I., Maduka, O., Onyekwere, V.N. and Tella, A.O. (2013) Awareness, acceptabiLity, and Use of Female Condoms among University Students in Nigeria: Implications for STI/HIV Prevention. The International Journal of Adolescent Medicine and Health, 1, 1-7.

[15] Ajaegbu, O.O. (2015) Premarital Sex, HIV and Use of Condom among Youths in Nigeria. Arts and Social Sciences Journal, 6, 146.

[16] Gebresllasie, F., Tsadik, M. and Berhane, E. (2017) Potential Predictors of Risk Sexual Behavior among Private College Students in Mekelle City, North Ethiopia. Pan African Medical Journal, 28, 151. https://doi.org/10.11604/pamj.2017.28.151.5370

[17] Liu, Z., Wei, P., Huang, M., Liu, Y., Li, L., Gong, X., et al. (2014) Determinants of Consistent Condom Use among College Students in China: Application of the Information-Motivation-Behavior Skills (IMB) Model. PLoS ONE, 9, e108976. https://doi.org/10.1371/journal.pone.0108976

[18] Ajayi, A.I., Nwokocha, E.E., Akpan, W., Adeniyi, O.V. and Goon, D.T. (2017) "It's Sweet without Condom": Understanding Risky Sexual Behaviour among Nigerian Female University Students. Online Journal of Health and Allied Sciences, 16, 9. https://doi.org/10.1186/s12889-016-3707-4

[19] Abdullahi, H., Okafor, C.J., Essien, E. and Udofia, O. (2017) Problematic Hypersexuality: Findings among Undergraduates in a Nigerian University. Global Journal of Medicine \& Public Health, 6, 2277-9604.

[20] Adinma, J.I.B., Adinma, E.D., Eke, N.O. and Umeononihu, O.S. (2016) Condom-Use by Students in a Higher Educational Institution in South Eastern Nigeria. Journal of Community \& Public Health Nursing, 2, 127. https://doi.org/10.4172/2471-9846.1000127

[21] Nwagwu, W.E. (2017) Social Networking, Identity and Sexual Behaviour of Undergraduate Students in Nigerian Universities. The Electro Library, 35, 534-558. https://doi.org/10.1108/EL-01-2015-0014 
[22] Gelibo, T. and Alemayehu, A. (2015) Consistent Condom Use and Preference of HIV Risk Preventive Interventions among Undergraduate University Students in Southern Ethiopia: A Cross Sectional Study. Journal of AIDS \& Clinical Research, 6 , 442. https://doi.org/10.4172/2155-6113.1000442

[23] Nwaokoro, J.C., Ede, A.O., Ibe, S.N.O., Emerole, C.O., Nwufo, R.C., Nwaokoro, A.A. and Igwe, I. (2015) Knowledge, Attitude and Practice of Female Condom Use among Undergraduates of Three Selected Higher Institutions in Owerri, South-Eastern, Nigeria. Global Advanced Research Journal of Medicine and Medical Sciences, 4, 132-142.

[24] Akpan, U.B., Ekott, M.I. and Udo, A.E. (2014) Male Condom: Knowledge and Practice among Undergraduates of a Tertiary Institution in Nigeria. International Journal of Gynecology \& Obstetrics, 2, 32-39. 